\section{Perancangan dan Produksi Modul Surya 24o Wp untuk Proyek Pembangkit Listrik Tenaga Surya (PLTS) - Independent Power Producer (IPP) di Kupang, Nusa Tenggara Timur}

\author{
Asep Sopandi ${ }^{1}$ Rasional Sitepu ${ }^{2}$ Andrew \\ Joewono 3
}

\begin{abstract}
${ }^{1}$ Program Studi Program Profesi Insinyur, Universitas Katolik Widya Mandala Surabaya
\end{abstract}

2 Program Studi Program Profesi Insinyur, Universitas Katolik Widya Mandala Surabaya

3 Program Studi Program Profesi Insinyur, Universitas Katolik Widya Mandala Surabaya

$\triangle$ andrew_sby@ukwms.ac.id

\begin{abstract}
Modul surya merupakan komponen yang utama dengan karakteristik yang baik dari Pembangkit Listrik Tenaga Surya ( PLTS). Modul surya dibuat dari serangkaian sel surya yang diinterkoneksi secara seri dan atau paralel untuk mendapatkan karakteristik listrik yang sesuai dengan tuntutan desain sistem PLTS yang akan dibangun. Modul surya juga dibentuk dari lembaran kaca khusus dengan kandungan besi rendah, lembaran bahan- bahan polimer, bahan logam untuk interkoneksi antar sel dan alat keluaran yang berfungsi menunjang sifat mekanik, elektrik dan ketahanan modul surya. Pembahasan cara perancangan modul surya, dijelaskan mulai dari dasar-dasar perancangan, spesifikasi modul surya yang akan dibuat, data-data sel surya dan syarat-syarat perancangan sesuai dengan standar kualitas modul surya. Sebagai contoh aplikasi modul surya yang dibuat jenis modul surya silikon polikristalin seri 240 Wp yang digunakan pada proyek pembangkit listrik tenaga surya Independent Power Producer (IPP) Kupang 5 Mwp tahun 2015. Serta diuraikan tahapan proses produksi modul surya dan penetapan parameter-parameter proses produksi sesuai dengan sifat dan jenis bahan yang ada dan proses produksi. Karakteristik listrik modul surya dengan menganalisa Daya maksimum (Pmax), Tegangan maksimum (Vmp), Arus maksimum (Imp), Tegangan rangkaian terbuka (Voc), Arus hubung singkat (Isc), efisiensi dan Fill factor dengan menggunakan peralatan sun simulator.
\end{abstract}

Kata kunci : Modul Surya, Sel Surya, Polikristalin.

Diajukan: 24 April 2021

Direvisi: 18 Mei 2021

Diterima: 20 Mei 2021

Dipublikasikan online: 25 Mei 2021

\section{Pendahuluan}

Salah satu sumber energi yang menjadi andalan dalam memenuhi target bauran energi baru terbarukan (EBT) yang dicanangkan pemerintah sebesar $23 \%$ pada tahun 2025 adalah sumber energi dari matahari, berupa Pembangkit Listrik Tenaga Surya (PLTS). Banyak keunggulan yang dimiliki PLTS dibanding dengan sumber EBT yang lain diantaranya potensi radiasi matahari yang tersebar merata di seluruh wilayah Indonesia, kemudahan pembangunan dan pemasangan, teknologi yang sudah cukup berkembang dan terbukti. Kelemahan PLTS terutama sumber energi matahari, sangat dipengaruhi oleh faktor cuaca harian dan sumber energi matahari tidak tersedia di malam hari.

Dilihat dari koneksi ke jaringan grid PLN, maka PLTS di klasifikasikan menjadi PLTS On-Grid dan PLTS Off-Grid. PLTS On-Grid adalah PLTS yang energi keluarannya langsung diinjeksikan ke jaringan PLN, sedangkan PLTS Off-Grid adalah PLTS yang keluarannya langsung digunakan, tanpa melibatkan jaringan PLN dan menggunakan batere sebagai penyimpan energi listrik yang dihasilkan dari konversi PLTS nya. (Sitepu \& Gunadhi, 2014)
Dilihat dari penerapannya, dikenal dengan sistem PLTS murni dan PLTS Hybrid. PLTS Hybrid adalah PLTS yang digabungkan dengan sumber energi lainnya, baik dengan sumber EBT lainnya misalkan energi angin ataupun sumber energi non-EBT seperti Diesel.

Struktur komponen PLTS secara umum terdiri dari alat pencatu daya berupa modul surya (panel surya), inverter, combiner box, panel proteksi , Battery Charge Regulator dan battery. Seperti pada Gambar 1. dan Gambar 2.,

Pada bagian ini, dijelaskan cara merancang modul surya untuk PLTS dan cara memproduksinya dari tahapan fabrikasi modul surya, penentuan parameter kualitas modul surya dan pengukuran karakteristik modul surya yang diproduksi. Perancangan dan produksi akan diaplikasikan pada proyek PLTS 5 MWp IPP di Kupang, Nusa Tenggara Timur, menggunakan modul surya silikon polikristalin seri 240 Wp. (PLN, 2015)

\section{Metode}

Perancangan modul surya pada umumnya merupakan interkoneksi dan enkapsulasi menjadi sel surya, untuk dapat menghasilkan tegangan, arus dan daya yang cukup besar

Cara mensitasi artikel ini:

Sopandi, A., Sitepu, R., Joewono, A. (2021) Perancangan dan Produksi Modul Surya 240 Wp untuk Proyek Pembangkit Listrik Tenaga Surya (PLTS) - Independent Power Producer (IPP) di Kupang, Nusa Tenggara Timur. Buletin Profesi Insinyur 4(1) 029-037 


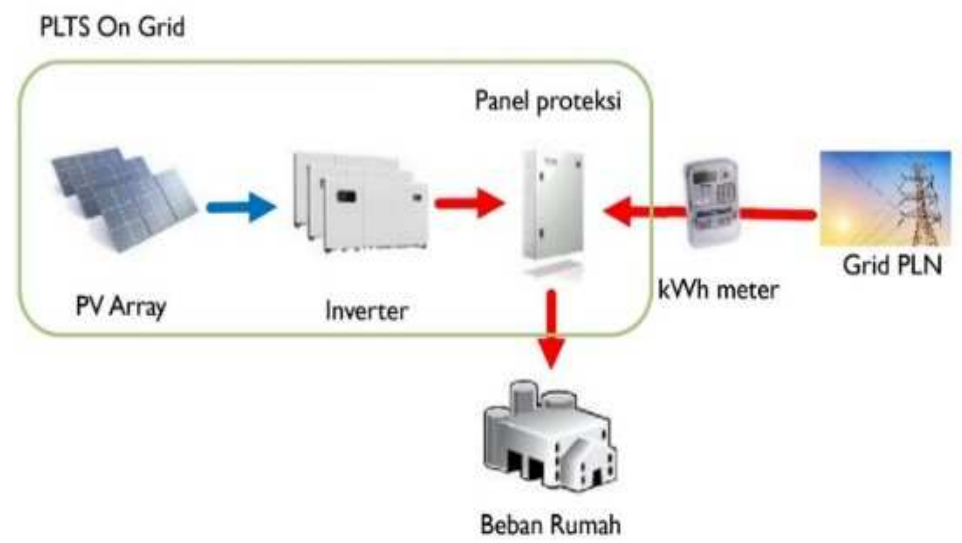

Gambar 1. Komponen PLTS On-Grid

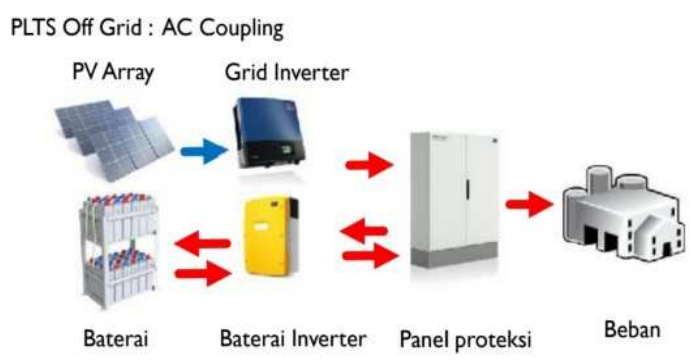

PLTS Off Grid : DC Coupling

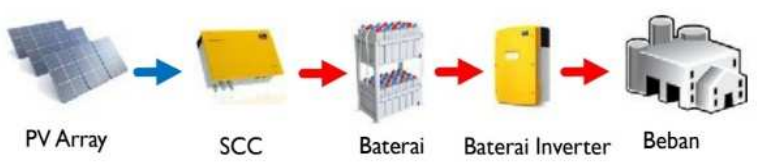

Gambar 2. Komponen PLTS OFF-Grid DC dan AC Coupling

untuk digunakan dalam implementasinya. Karakteristik listrik modul surya umumnya ditunjukkan oleh kurva ArusTegangan (I-V) yang sangat ditentukan oleh karakteristik listrik solar selnya. Idealnya, bila solar sel mempunyai karakteristik yang hampir sama atau identik, maka karakteristik kurva I-V modul surya akan mempunyai karakteristik yang sama dengan skala nilai yang lebih besar. Namun dalam praktek skala produksi, solar sel tidak pernah memiliki bentuk kurva I-V yang sama persis (Green, 2009).

Dalam hal ini maka karakteristik modul surya akan ditentukan atau dibatasi oleh solar sel dengan kualitas dan keluaran yang paling rendah. Selain dirancang untuk memiliki karakteristik listrik yang handal dan sesuai dengan kebutuhan sistem PLTS, modul surya juga dirancang untuk memiliki sifat mekanis yang kuat, tahan terhadap gangguan atau tekanan cuaca dan iklim pada saat penggunaannya. Oleh karena itu, dalam perancangan modul surya juga perlu dipertimbangkan pemilihan bahan material pendukungnya, seperti kaca, polimer, bahan interkoneksi antar solar sel, kerangka, perangkat keluaran berupa Junction-Box termasuk bahan adhesifnya.

Karakteristik Listrik Solar Sel dan Modul Surya (S.R., M.A., \& M.E., 1998)

Solar sel silikon pada dasarnya adalah sebuah dioda yang dibentuk dari silikon tipe $\mathrm{N}$ (didoping oleh atom Fosfor) dan silikon tipe $\mathrm{P}$ (didoping oleh atom Boron). Karakteristik listrik solar sel dan modul surya diilustrasikan pada Persamaan (1). Ketika partikel foton dari sinar matahari mengenai solar sel, maka akan membentuk pasangan elektron (-) dan hole (+). Medan listrik yang terbentuk pada $P N$-Junction dalam solar sel akan menyapu elektron ke arah lapisan $\mathrm{N}$ dan hole ke arah lapisan $\mathrm{P}$, sehingga menghasilkan aliran elektron atau arus listrik. Persamaan (1) karakteristik dioda tanpa penyinaran adalah :

$$
I=I_{0}\left(\operatorname{Exp}^{(\mathrm{qV} / \mathrm{KT}}-1\right)
$$

dimana :

I = Arus yang mengalir pada PN-Junction (solar sel), akibat adanya beda polaritas

$\mathrm{I}_{\mathrm{o}}=$ "Dark Saturation Current", yaitu rapat arus bocor dioda ketika tidak ada cahaya

$\mathrm{Q}=$ Muatan listrik

$\mathrm{K}=$ Tetapan Boltzman

$\mathrm{T}=$ Temperatur mutlak Kelvin

Io akan naik nilainya, bila temperatur nilainya naik, dan akan turun nilainya, bila kualitas $P N$ - Junction semakin baik.

Bila terjadi penyinaran, maka akan terbentuk tegangan listrik dalam solar sel, akibat terbentuknya perpindahan pasangan elektron-hole, sesuai dengan persamaan (2) :

$$
I=I_{p h}-I_{0}\left(\operatorname{Exp}^{(q V / K T}-1\right)
$$


$I_{p h}=$ Arus yang timbul akibat penyinaran.

Persamaan tersebut dapat digambarkan sebagai kurva I-V, seperti pada Gambar 3.

Pada Gambar 3, terlihat beberapa parameter yang menggambarkan karakteristik listrik solar sel dan modul surya antara lain : Daya maksimum $\left(P_{m p}\right)$, Tegangan terbuka $V_{\text {oc }}$, Arus hubung singkat $I_{s c}$, Tegangan pada daya maksimum $\mathrm{V}_{\mathrm{mp}}$, dan arus pada daya maksimum $\mathrm{I}_{\mathrm{mp}}$.

\section{Tahapan Perancangan Pembuatan Modul Surya}

Perancangan modul surya umum dilakukan untuk menghasilkan dokumen rancangan, spesifikasi peralatan, tahap prototyping dan pengukuran-pengetesan hasil produk, dengan tahap sebagai berikut :

1. Pemilihan dan penentuan jenis solar sel

2. Pencarian data solar sel terkini

3. Pemilihan solar sel

4. Perancangan karakteristik listrik modul surya

5. Perancangan mekanik dan dimensi fisik modul surya

6. Pembuatan gambar fisik modul surya

7. Penentuan spesifikasi bahan-bahan atau komponen pendukung

8. Penentuan parameter-parameter proses produksi untuk pembuatan prototyping

9. Pengukuran karakteristik listrik modul surya hasil produksi

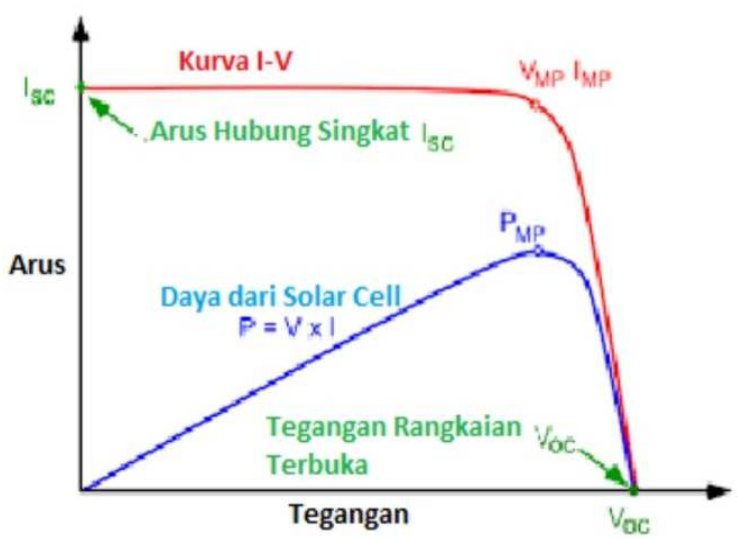

Gambar 3. Kurva Arus- Tegangan (I-V) dari solar sel ataupun modul surya.

\section{Hasil Kerja}

\section{Perancangan Modul Surya Polikristalin seri $240 \mathrm{Wp}$}

1. Pemilihan dan Penentuan Jenis Solar Sel

Pemilihan dan penentuan jenis solar sel berdasarkan pada pertimbangan nilai efisiensi solar sel, yang akan menentukan besar daya yang dihasilkan tiap selnya serta pertimbangan harga. Secara umum solar sel jenis monokristalin mempunyai capaian daya maksimum tiap sel lebih tinggi dibanding polikristalin namun harga juga relatif lebih tinggi. sebagai pertimbangan dalam perancangan apabila perhitungan parameter dapat disediakan oleh solar sel jenis polikristalin, maka dipilih solar sel jenis polikristalin, kecuali ada pertimbangan lain, misalnya kebutuhan efisiensi sel yang tinggi dengan luasan lahan yang terbatas.

Untuk perancangan proyek ini diputuskan menggunakan solar sel jenis polikristalin untuk modul surya seri $240 \mathrm{Wp}$.
2. Pencarian Data Solar Sel Terkini

Pencarian data solar sel dilakukan untuk mengetahui perkembangan terkini dari solar sel yang diproduksi di dunia. Perkembangan tersebut dapat berupa perkembangan penggunaan material baru, proses fabrikasi terbaru, modifikasi struktur dan susunan material maupun perkembangan efisiensi yang dicapai oleh solar sel jenis tertentu. Data yang paling penting dan relevan untuk proses perancangan adalah perkembangan capaian efisiensi solar sel untuk jenis yang akan dipakai. Proses pencarian dilakukan dengan meminta data dari pabrikan.

\section{Data Solar Sel untuk Modul Surya jenis Polikristalin seri 240} Wp

Modul surya seri $240 \mathrm{Wp}$ ini digunakan pada proyek Pembangkit Listrik Tenaga Surya (PLTS) IPP Kupang kapasitas 5 MWp dibangun pada tahun 2015. Data solar sel dari perusahaan "Jetion Solar China Co.,Ltd", seperti pada Tabel 1-4.

Tabel 1. Mechanical Data and Design

\begin{tabular}{ll} 
Format & $156 \mathrm{~mm} \times 156 \mathrm{~mm}+-0,5 \mathrm{~mm}$ \\
Thickness & $210 \mathrm{mikron}+-40$ mikron \\
Front(-) & $\begin{array}{l}1,4 \mathrm{~mm} \text { bus bars( silver), blue anti-reflection } \\
\text { coating ( silicon nitride) }\end{array}$ \\
Back (+) & $\begin{array}{l}2,4 \mathrm{~mm} \text { wide soldering pads (silver)back surface } \\
\text { field (aluminum) }\end{array}$ \\
\hline
\end{tabular}

Tabel 2. Temperature Coefficient Of Sels

\begin{tabular}{ll}
\hline $\mathbf{V}_{\text {oc. }}$ Temp. Coef. $\% / \mathbf{K}$ & $-0,351 \% / \mathrm{K}$ \\
$\mathbf{I}_{\text {sc }} \cdot$ Temp. Coef. $\% / \mathbf{K}$ & $+0,035 \% / \mathrm{K}$ \\
$\mathbf{P}_{\mathrm{m}}$. Temp. Coef. $\% / \mathbf{K}$ & $-0,47 \% / \mathrm{K}$ \\
\hline
\end{tabular}

3. Pemilihan Solar Sel setelah tahap produksi Hasil produksi solar sel umumnya tidak menghasilkan kualitas solar sel dalam satu kelas dari nilai karakteristik listrik tertentu. Hasil produksi mengikuti pola distribusi normal, yaitu solar sel dengan kualitas karakteristik menengah akan dihasilkan lebih banyak jumlahnya, sedangkan solar sel dengan kualitas karakteristik rendah dan tinggi jumlahnya sedikit.

Tabel 3. Electrical Characteristic

\begin{tabular}{lllllll}
\hline Class & $\mathbf{E f f}(\%)$ & $\begin{array}{l}\mathbf{P}_{\mathbf{m p}} \\
(\mathbf{W})\end{array}$ & $\begin{array}{l}\mathbf{V}_{\mathbf{m p}} \\
(\mathbf{V})\end{array}$ & $\begin{array}{l}\mathbf{I}_{\mathbf{m p}} \\
(\mathbf{A})\end{array}$ & $\begin{array}{l}\mathbf{V}_{\mathbf{o c}} \\
(\mathbf{V})\end{array}$ & $\mathbf{I}_{\mathbf{s c}}(\mathbf{A})$ \\
\hline 182 & 18,2 & 4,43 & 0,536 & 8,263 & 0,643 & 8,712 \\
180 & 18,0 & 4,38 & 0,535 & 8,188 & 0,633 & 8,701 \\
178 & 17,8 & 4,33 & 0,534 & 8,112 & 0,632 & 8,652 \\
176 & 17,6 & 4,28 & 0,533 & 8,036 & 0,631 & 8,641 \\
174 & 17,4 & 4,23 & 0,529 & 8,005 & 0,630 & 8,591 \\
172 & 17,2 & 4,19 & 0,525 & 7,973 & 0,627 & 8,542 \\
170 & 17,0 & 4,14 & 0,522 & 7,926 & 0,634 & 8,495 \\
168 & 16,8 & 4,09 & 0,518 & 7,893 & 0,620 & 8,452 \\
166 & 16,6 & 4,04 & 0,515 & 7,844 & 0,617 & 8,410 \\
164 & 16,4 & 3,99 & 0,514 & 7,765 & 0,616 & 8,373 \\
162 & 16,2 & 3,94 & 0,511 & 7,715 & 0,615 & 8,317 \\
160 & 16,0 & 3,89 & 0,509 & 7,650 & 0,613 & 8,251 \\
158 & 15,8 & 3,85 & 0,502 & 7,660 & 0,610 & 8,121 \\
154 & 15,4 & 3,75 & 0,501 & 7,481 & 0,608 & 8,023 \\
150 & 15,0 & 3,65 & 0,499 & 7,315 & 0,604 & 7,833 \\
\hline
\end{tabular}

Data under STC (Standard Testing Condition) 1000W/ $/ \mathrm{m}^{2}$, AM $1.5,25^{\circ} \mathrm{C}$

4. Perancangan Karakteristik Listrik Modul Surya Polikristalin seri $240 \mathrm{Wp}$

Perancangan karakteristik listrik modul surya dilakukan, meliputi perhitungan jumlah solar sel dan konfigurasi 
interkoneksinya untuk mencapai nilai-nilai karakteristik listrik yang diinginkan (seri atau paralel), tegangan, arus, daya, efiesiensi , sesuai dengan parameter sistem PLTS yang dirancang.

Tabel 4. Intensity Dependence

\begin{tabular}{ccc}
\hline Intensity $\left(\mathbf{W} / \mathbf{m}^{2}\right)$ & $\mathbf{I}_{\mathbf{s c}} \mathbf{x}(\mathbf{m A})$ & $\mathbf{V}_{\text {oc }} \mathbf{x}(\mathbf{m} \mathbf{V})$ \\
\hline 1000 & 1,00 & 1,000 \\
900 & 0,90 & 0,989 \\
500 & 0,50 & 0,963 \\
300 & 0,30 & 0,939 \\
200 & 0,20 & 0,920 \\
\hline
\end{tabular}

Berdasarkan data solar sel dari Tabel 3., maka untuk pembangunan PLTS IPP Kupang diputuskan menggunakan solar sel dengan efisiensi $=17,4 \%$, Daya persel $(P)=4,23 \mathrm{~W}$, Tegangan pada titik daya maksimum mpp $\left(\mathrm{V}_{\mathrm{mp}}\right)=0,529 \mathrm{~V}$, Arus pada daya maksimum $\left(I_{\mathrm{mp}}\right)=8,005 \mathrm{~A}$, Tegangan terbuka $\left(V_{o c}\right)=0,630 \mathrm{~V}$ dan arus hubung singkat $\left(I_{s c}\right)=8,591$ A.

Berdasarkan pertimbangan berat, modul surya yang akan dikirim ke lokasi, kemudahan instalasi di lapangan dan untuk kemudahan mobilisasi maka diputuskan membuat modul dengan jumlah solar sel 60 buah/ keping per modul. Dari data solar sel yang telah dipilih, maka karakteristik modul surya yang dibuat akan memiliki karateristik listrik sebagai berikut :

a. Daya modul surya (Luque \& Hegedus, 2011)

Solar sel sebanyak 60 buah dikoneksikan secara seri, maka didapat :

Daya modul surya $(\mathrm{P})$ = Jumlah solar sel $\times$ Daya persel ..(3)

$$
\begin{aligned}
& =60 \times 4,23 \text { watt } \\
& =253,8 \mathrm{Watt}
\end{aligned}
$$

Karena adanya kehilangan Ohmic (Ohmic losses), terutama pada bahan tabbing (bahan tembaga berbentuk foil yang menghubungkan solar sel yang satu dengan yang lain dengan proses solder), kehilangan optik dan pengaruh ketidakseragaman karakteristik solar sel, maka daya akan berkurang sebesar 3\% sd 4\% (Luque \& Hegedus, 2011), sehingga daya modul surya menjadi $=253,8 \times 0,96=243,65$ Watt.

b. Tegangan $\mathrm{V}_{\mathrm{mp}}$ Modul Surya

Tegangan $\mathrm{V}_{\mathrm{mp}}$ modul surya adalah tegangan modul surya pada titik daya maksimum. Dengan 60 buah solar sel dikoneksi secara seri, maka tegangan $\mathrm{V}_{\mathrm{mp}}$ modul adalah :

$$
\begin{aligned}
\text { Vmp modul } & =60 \times V_{m p} \text { Sel } \\
& =60 \times 0,529 \\
& =31,74 \text { Volt }
\end{aligned}
$$

\section{Arus Imp Modul Surya}

Arus $I_{m p}$ modul surya adalah kuat arus modul surya pada titik daya maksimum. Dengan 60 buah solar sel dikoneksi secara seri, maka nilai kuat arus modul surya :

Imp modul surya $=I_{m p}$ solar sel $=8,005 \mathrm{~A}$

\section{d. Tegangan Terbuka $\mathrm{V}_{\text {oc }}$ Modul Surya}

Seperti halnya dengan tegangan pada titik daya maksimum, tegangan terbuka $\mathrm{V}_{\text {oc }}$ modul surya adalah perkalian jumlah sel dengan nilai tegangan $\mathrm{V}_{\text {oc }}$ solar selnya.

Voc modul surya $=$ Jumlah sel $x V_{\text {oc }}$ sel.

$$
=60 \times 0,630
$$

$$
=37,8 \text { Volt }
$$

e. Arus Hubung singkat $I_{s c}$ Modul Surya

Seperti halnya arus pada titik daya maksimum, maka arus hubung singkat modul surya :

Arus hubung singkat $\mathrm{I}_{\mathrm{sc}}$ modul surya $=$ Arus hubung singkat solar selnya $=8,591 \mathrm{~A}$

f. Efisiensi Solar sel dan Modul surya (IEC 61215-1-1 :2016 Terrestrial Photovoltaic (PV) module, 2016)

Perhitungan efisiensi solar sel maupun modul surya diuraikan sebagai berikut :

- Nilai Irradian sinar matahari ketika sampai ke bumi adalah $1000 \mathrm{Watt} / \mathrm{m}^{2}$

- Bila solar sel atau modul surya memiliki efisiensi $100 \%$, maka dengan solar sel atau modul surya yang memiliki luas $1 \mathrm{~m}^{2}$ akan menghasilkan daya 1000 Watt.

- Dari Tabel 1. dapat dilakukan perhitungan luasan 1 buah solar sel adalah $156 \times 156 \mathrm{~mm}=24336 \mathrm{~mm}^{2}=0,0243 \mathrm{~m}^{2}$.

- Bila solar sel memiliki efisiensi $100 \%$, maka dengan luasan $0,0243 \mathrm{~m}^{2}$ akan dihasilkan daya $=0,0243 \times 1000=24,3 \mathrm{~W}$.

- Solar sel yang digunakan untuk membuat modul surya 240 $\mathrm{Wp}$, menghasilkan daya 4,04 W untuk luasan $0,0243 \mathrm{~m}^{2}$. Jadi,

$$
\begin{aligned}
\text { efisiensi } & =(\text { Daya Sel }) \times 1000) /(\text { LXW }) \\
& =4,23 \times 1000 / 24336 \\
& =0,1738 \text { atau } 17,38 \%
\end{aligned}
$$

\begin{tabular}{|c|c|c|c|c|}
\hline No & Parameter & $\begin{array}{l}\text { Solar } \\
\text { sel }\end{array}$ & Perhitungan & $\begin{array}{l}\text { Modul } \\
\text { surya }\end{array}$ \\
\hline 1 & Daya P (W) & 4,23 & $60 \times(4,23) \times 0.96$ & 243,65 \\
\hline 2 & $\begin{array}{l}\text { Tegangan } \mathrm{V}_{\mathrm{mp}} \\
\text { ( V) }\end{array}$ & 0,52 & $60 x(0,529)$ & 31,74 \\
\hline 3 & Arus $I_{m p}(A)$ & 8,005 & $\begin{array}{l}I_{\mathrm{mp}} \mathrm{sel}=\mathrm{Imp} \\
\text { modul }\end{array}$ & 8,005 \\
\hline 4 & $\begin{array}{l}\text { Tegangan } \\
\text { terbuka } \mathrm{V}_{\mathrm{oc}} \\
\text { (V) }\end{array}$ & 0,630 & $60 x(0,630)$ & 37,8 \\
\hline 5 & $\begin{array}{l}\text { Arus hubung } \\
\text { singkat } I_{\text {sc }}(\mathrm{A})\end{array}$ & 8,591 & $\mathrm{I}_{\mathrm{sc}} \mathrm{sel}=\mathrm{I}_{\mathrm{sc}}$ modul & 8,591 \\
\hline 6 & Efisiensi (\%) & 17,4 & $243,65 /(1607,2)$ & 15,16 \\
\hline
\end{tabular}

Efisiensi modul surya $=($ Daya yang dihasilkan $) \times 1000 /($ Luas modul surya)

$$
\begin{aligned}
& =243,65 \times 1000 /(1607180) \\
& =15,16 \%
\end{aligned}
$$

Hasil perancangan karakteristik listrik modul surya seri 240 Wp disajikan pada Tabel 5.

Tabel 5. Perhitungan Karakteristik Listrik Modul Surya Polikristalin $240 \mathrm{Wp}$

Perancangan Mekanik dan Dimensi Fisik Modul Surya Polikristalin Seri $240 \mathrm{Wp}$

Perancangan mekanik dan dimensi fisik modul surya meliputi penetapan jumlah baris dan kolom solar sel dalam modul surya, penetapan jarak antar solar sel serta jarak antara solar sel dengan tepi modul surya. Jarak antara solar sel mengikuti standard IEC atau SNI-IEC 61730-1, khususnya mengenai jarak rambat (Creepage Distance) dan Jarak ruang (Clearance Distance). (Luque \& Hegedus, 2011) (IEC 617301: 2008 Photovoltaic (PV) module safety qualification, 2008)

Solar sel pada modul surya disusun dalam tata letak berupa baris dan kolom. Jumlah kolom diambil genap mulai 
dari 2, 4, 6, sedangkan jumlah baris tidak dibatasi. Kerentanan kaca (pecah) ketika modul surya mempunyai ukuran fisik terlalu besar, sebagai pertimbangan dalam menentukan jumlah sel dalam modul surya serta berat fisiknya. Berat modul surya perlu menjadi bahan pertimbangan ketika letak lokasi pemasangan jauh di daerah terpencil dan keterbatasan alat angkut. Modul yang terlalu berat dapat menyulitkan proses instalasi.

Perancangan mekanik dan fisik modul surya seri 240 $W p$ adalah sebagai berikut :

- Dari Tabel 1. diketahui dimensi solar sel adalah $156 \mathrm{~mm}$ x $156 \mathrm{~mm}$

- Untuk membuat modul pada kisaran $240 \mathrm{Wp}$, diperlukan solar sel 60 buah dengan konfigurasi 6 kolom dan 10 baris.

- Penentuan Panjang Kaca modul surya adalah : (IEC 617301: 2008 Photovoltaic (PV) module safety qualification, 2008)

$\mathrm{L}_{\mathrm{ms}}=\left(10 \times \mathrm{L}_{\mathrm{sc}}\right)+(9 \mathrm{x}$ jarak antar sel vertikal $)+(2 \mathrm{x}$

Jarak solar sel ke tepi modul atas dan bawah).

$\begin{aligned} \mathrm{L}_{\mathrm{ms}} & =(10 \times 156)+(9 \times 2)+(2 \times 26) \\ & =1560+18+52\end{aligned}$

$=1630 \mathrm{~mm}$

$L_{\text {frame }}=1630+6=1636 \mathrm{~mm}$

dimana :

$\mathrm{L}_{\mathrm{ms}} \quad$ = Panjang Kaca modul surya

$\mathrm{L}_{\mathrm{sc}} \quad=$ Panjang solar sel

Lrame = Panjang frame Aluminum

- Penentuan lebar Kaca Modul Surya adalah : (IEC 61730-1: 2008 Photovoltaic (PV) module safety qualification, 2008) $\mathrm{W}_{\mathrm{ms}}=\left(6 \times \mathrm{W}_{\mathrm{sc}}\right)+(5 \times$ Jarak antar sel horizontal $)+(2$ $x$ Jarak solar sel ke tepi modul kiri dan kanan) .....(11)

$\mathrm{W}_{\mathrm{ms}}=(6 \times 156)+(5 \times 3)+(2 \times 17,5)$

$=936+15+35$

$=986 \mathrm{~mm}$

$W_{\text {frame }}=986+6=992 \mathrm{~mm}$

dimana :
$\mathrm{W}_{\mathrm{ms}} \quad=$ Lebar Kaca modul surya

$\mathrm{W}_{\mathrm{sc}} \quad=$ Lebar solar sel

$\mathrm{W}_{\text {frame }}=$ Lebar frame Aluminum.

Konstruksi Modul surya seri $240 \mathrm{Wp}$, seperti terlihat pada Gambar 4 dan 5. Gambar skematik mekanik modul surya seri 240 Wp disajikan pada Gambar 4 dan gambar fisik modul disajikan pada Gambar 5.

\section{Penentuan Spesifikasi Bahan-Bahan Pendukung}

Komponen pembuatan modul surya terdiri dari : String dan busbar ribbon, kaca, bahan polimer untuk enkapsulasi dan back-sheet, frame (bingkai berbahan antikorosi), junctionbox, bahan adhesif, sealant dan bahan packagingnya.

Struktur komponen pembuatan modul surya terlihat pada Gambar 6.

Fungsi dari komponen dijelaskan sebagai berikut :

a. String dan Busbar ribbon

String ribbon berfungsi sebagai koneksi elektrik antara solar sel dengan proses penyolderan (alat solder manual atau mesin stringer). Busbar ribbon berfungsi sebagai koneksi elektrik antar rangkaian solar sel (array). String ribbon dan bus ribbon terbuat dari lembar tembaga yang dilapisi timah.

Spesifikasi,

- Bahan : Tin- Coated Copper Ribbon

- Dimensi : String Ribbon 0.23*1.5 mm

- Bus Ribbon : 0.35*5.0 mm

- Standard : 2011/65/EU, ISO 17075:2007, EN62321:2009

- Pabrik : Suzhou Yubang New material Co. Ltd.

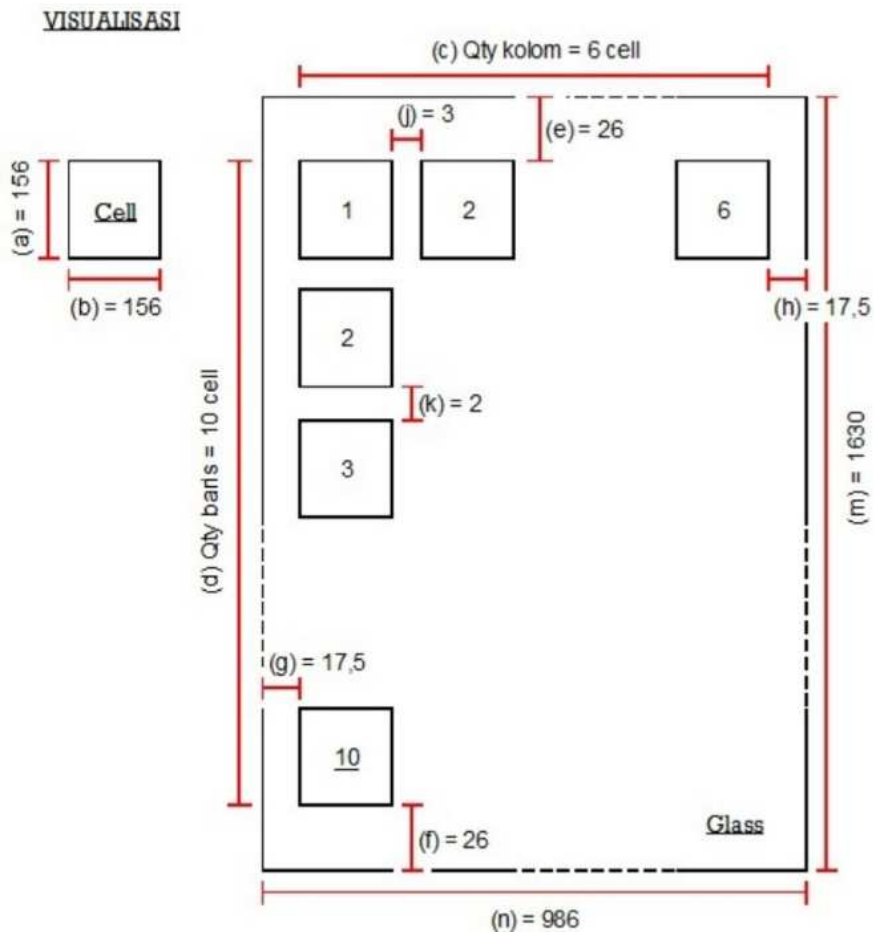

Gambar 4. Skematik Mekanik Modul Surya seri 240 Wp 


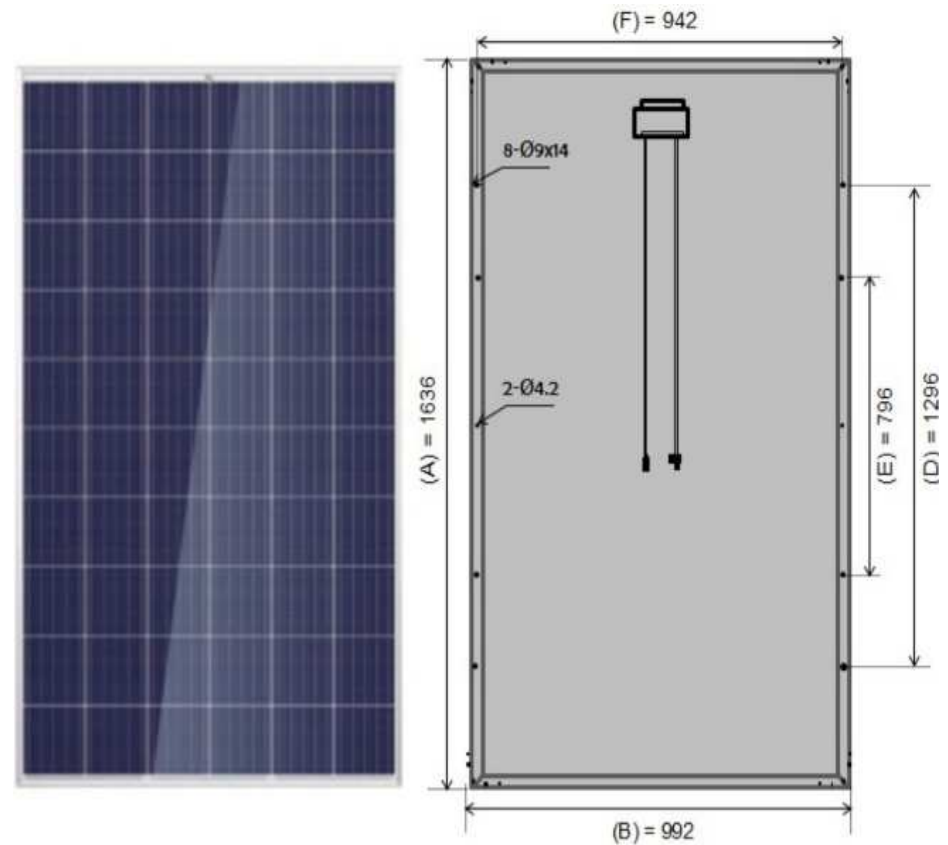

Gambar 5. Tampak Depan dan Belakang Modul surya seri $240 \mathrm{Wp}$

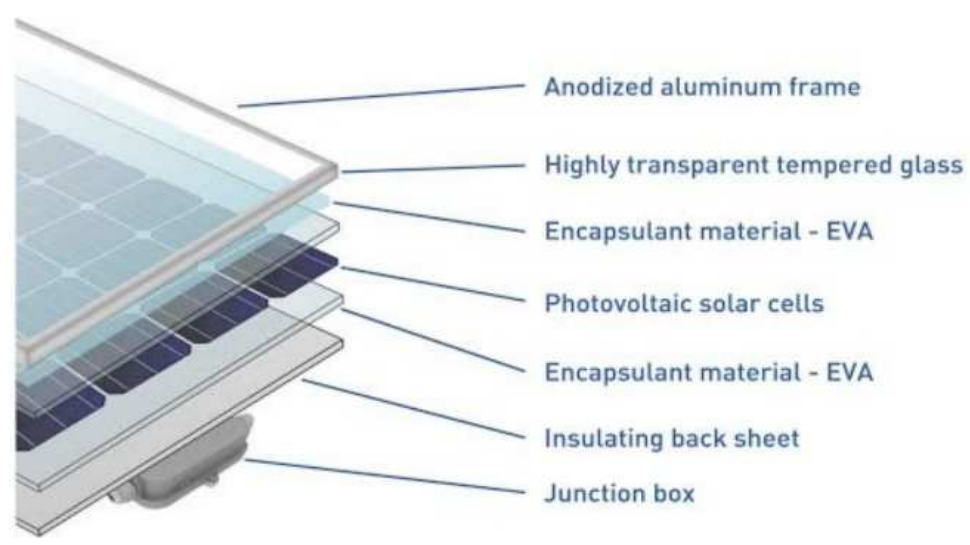

Gambar 6. Struktur komponen pembuatan modul surya

b. Bahan Enkapsulasi Etilen Vinil Asetat (EVA)

Bahan enkapsulasi digunakan agar modul surya tahan terhadap penetrasi uap air, gas dan cairan, ketika digunakan di lapangan dalam jangka waktu 20 sampai 25 tahun (S.R., M.A., \& M.E., 1998). Bahan enkapsulasi juga harus tahan mengalami beda potensial minimal sama dengan tegangan sistem PLTS. Bahan yang digunakan adalah kopolimer Etilen vinil asetat, sejenis plastik yang terdiri dari rangka atom karbon yang panjang. EVA bersifat termoplastik, bahan ini akan berubah bentuk secara reversibel ketika dipanaskan. Kedalam EVA umumnya ditambahkan "curing agent" dan stabiliser UV. (Luque \& Hegedus, 2011) Spesifikasi,

- Bahan : Etilen Vinil Asetat ( EVA)

- Ketebalan : $0.45-0.5 \mathrm{~mm}$

- Temperatur laminating : $140-150^{\circ} \mathrm{C}$

- Waktu Vacum : 4-6 menit

- Waktu Tekan : 10-14 menit

- Pabrik : Hangzhou First PV Material Co. Ltd c. Back-sheet

Back-sheet merupakan bahan polimer pada lapisan belakang modul surya. Bahan ini berfungsi sebagai penghalang dari kelembaban dan proses korosi, serta sebagai isolasi elektrik untuk keamanan penggunaan modul surya. Back-sheet terdiri dari 3 lapis bahan, yaitu lapisan luar adalah tedlar, polimer fluoro buatan "Dupont" yang tahan terhadap penetrasi uap dan bahan cairan dari luar, tetapi tidak memiliki tahanan isolasi listrik untuk tegangan tinggi, sehingga dibuat lapisan kedua yaitu poliester, serta Lapisan ketiga adalah tedlar. Spesifikasi,

- Struktur bahan pelapis : lapisan luar Tedlar 25 mikron, lapisan tengah Poliester-tedlar 300 mikron dan lapisan polietilen 25 mikron

- Standard : IEC 60664-1:2007 dan IEC 61730-2: 2004

- Pabrik : Jiangsu Worldsun PV Technology Co. Ltd. 
d. Kaca

Lembaran kaca untuk memberikan rigiditas mekanis dan perlindungan terhadap modul surya. Kaca harus dalam bentuk tempered dan harus mempunyai kandungan ion besi rendah agar transmisi cahaya sebesar mungkin. (Luque \& Hegedus, 2011)

Spesifikasi,

- Ketebalan : $3,2 \mathrm{~mm}$

- Kandungan besi : $0,012 \%$

- Jenis :Tempered

- Pabrik : Hejiang Jiaju Glass Co. Ltd

e. Junction-Box (J-Box)

Perangkat ini berfungsi sebagai tempat terminal keluaran listrik dari modul surya.

Spesifikasi,

$\begin{array}{ll}\text { - Type } & \text { : PV GZX 156 K } \\ \text { - Konektor } & \text { : MC4 } \\ \text { - Rating Tegangan } & \text { : 1000 VDC } \\ \text { - Rating Arus } & : 12 \mathrm{~A} \\ \text { - Dioda } & : 16 \mathrm{~A} / 40 \mathrm{~V} \\ \text { - Tingkat Proteksi } & : \text { IP } 67 \\ \text { - Ukuran kabel } & : 4,0 \mathrm{~mm} \\ \text { - Kelas nyala } & \text { : UL94V-0 } \\ \text { - Pabrik } & \text { : Ningbo GZX PV }\end{array}$

f. Frame atau rangka

Frame berfungsi sebagai penambah kekuatan mekanis modul surya dan sebagai sarana untuk pemasangan modul surya pada tiang penyangga di lapangan.

Spesifikasi,

- Aluminum ekstrusi

- Anodized plating

g. Bahan sealant

Sealant adalah bahan polimer yang digunakan sebagai bahan kedap air dan udara yang diletakkan pada celah antara frame dan kaca, serta bahan pengecoran terminal pada J-Box.

Spesifikasi,

- Bahan : Dimetil siloksan

- Type : Tonsan 1527

- Pabrik : Tonsan

Proses Produksi dan Penentuan Parameter- Parameternya Tahapan proses produksi modul surya sebagai berikut : (Ismet, Sopandi, \& Sofyan, 1999)

1. Incoming Inspection, pada tahap ini dilakukan pemeriksaan kualitas dari komponen terutama solar sel

2. Soldering Tab dan string, pada tahap ini string ribbon disolder pada bagian atas solar sel, untuk membentuk rangkaian solar sel yang terhubung seri

3. Lay-up, pada tahap ini seluruh bahan komponen modul surya disusun secara berurutan dari atas ke bawah dengan urutan : Kaca, EVA, Solar Sel yang sudah dirangkai , EVA dan Back-sheet. Setiap string juga diinterkoneksikan secara seri dengan penyolderan busbar ribbon

4. Inspeksi EL-1, pada tahap ini bahan yang sudah disusun diinspeksi dengan sinar infra merah menggunakan alat EL untuk melihat adanya solar sel yang retak dan solder yang lepas. (Azwar, 2010)

5. Laminasi, pada tahap ini, seluruh bahan yang sudah disusun pada tahap lay-up dipanaskan, divakum dan dipress dalam mesin laminasi. Pada tahap ini lapisan EVA meleleh dan merekatkan seluruh bahan modul surya. Temperatur laminasi : $144^{\circ} \mathrm{C}$ dan tekanan $39-40$ bar.

6. Inspeksi EL-2, proses ini sama dengan tahap 4, untuk melihat micro-crack, adanya gelembung uap air dalam modul, sisa solder dan kesalahan lain setelah proses laminasi. (Dupont, 2019)

7. Pemasangan J-box dan Terminating, pada tahap ini dipasang komponen J-box yang berfungsi sebagai alat keluaran listrik dari modul surya

8. Flash Test Sun Simulator, pada tahap ini modul surya di tes dengan penyinaran pada kondisi standar yaitu Irradians $1000 \mathrm{Watt} / \mathrm{m} 2$ dan temperatur $25^{\circ} \mathrm{C}$. Sehingga didapatkan data karakteristik listrik modul surya, antara lain : Daya (Pmax), tegangan maksimum (Vmp), Arus maksimum (Imp), tegangan rangkaian terbuka ( Voc), Arus hubung singkat ( Isc), Efisiensi dan fill factor

9. Framming, pada tahap ini frame dipasangkan pada modul surya

10. Test Hi-pot dan continuity, pada tahap ini modul surya di tes pada tegangan tinggi dan dilakukan juga uji kontinuitas grounding.

11. Final inspection, pada tahap ini dilakukan pemeriksaan visual dan penempelan tanda lolos Quality Control (QC)

12. Packing, pada tahap ini modul surya dipacking dan siap masuk gudang.

Pengukuran Karakteristik Listrik Modul Surya Hasil Prototyping. (Faradilla, 2017)

Pengukuran karakteristik modul surya dilakukan menggunakan metode pengujian indoor, dengan fasilitas pengujian "SPIRE" sebagai Sun Simulator "SPIRE", yang akan menghasilkan pembacaan parameter pengukuran pada kurva I-V, terlihat pada Gambar 7-9.

Pengukuran dilakukan sebanyak 5 sampel, untuk mengetahui parameter nilai terukur $I_{m p}$ dan $I_{s c}$, untuk dapat diketahui nilai efisiensi dari modul surya yang dirancang dan diproduksi.

Dari hasil pengukuran dengan menggunakan sun simulator yang tertampilkan pada Gambar 7-11, didapatkan nilai parameter dari sampel terukur, nilai $I_{m p}$ berkisar antara 8,239 A hingga 8,349 A dan nilai $\mathrm{I}_{\mathrm{sc}}$ berkisar antara 8,613 A hingga 8,682 A. Nilai terukur ini akan dijadikan nilai parameter hasil produksi pembuatan modul surya (panel surya tersebut).

\section{Kesimpulan}

Modul polikristalin seri $240 \mathrm{Wp}$ dengan daya rancangan $243,65 \mathrm{Wp}$ dan efisiensi $15,16 \%$ menghasilkan modul surya hasil produksi, dengan daya rata-rata sebesar $249,77 \mathrm{Wp}$ dan efisiensi 15,39\%. Terjadi kenaikan 2,5\% dari perhitungan rancangan. Hal ini dikarenakan arus baik $I_{m p}$ maupun $I_{s c}$ hasil pengukuran Sun simulator lebih besar dari pada data sheet yang ada dari pabrikan solar sel. Penyebabnya kemungkinan besar karena kondisi temperatur pada saat pengukuran terjadi penyimpangan dari keadaan standard yaitu $25^{\circ} \mathrm{C}$. Secara teori, kenaikan temperatur dapat meningkatkan Arus Isc dan Imp (sesuai Tabel 2 dan Tabel 6 tentang temperature coefficient dari solar sel). Dengan demikian produksi modul surya yang akan digunakan dalam pembangunan PLTS IPP 5MWp di Kupang dapat digunakan. 

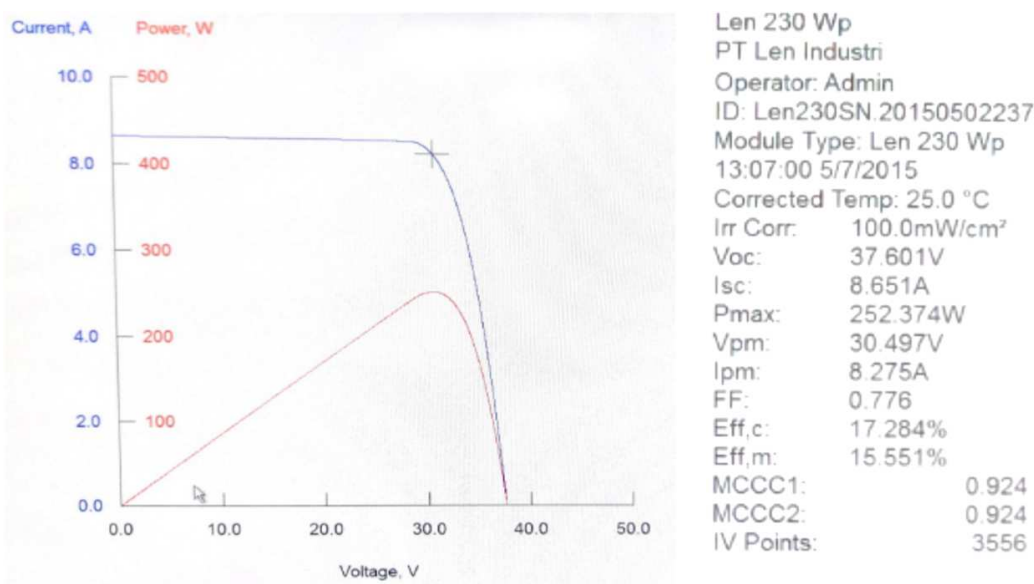

Gambar 7. Hasil Pengukuran Kurva I-V dan karakteristik listrik Modul Surya 240 Wp (sampel-1)
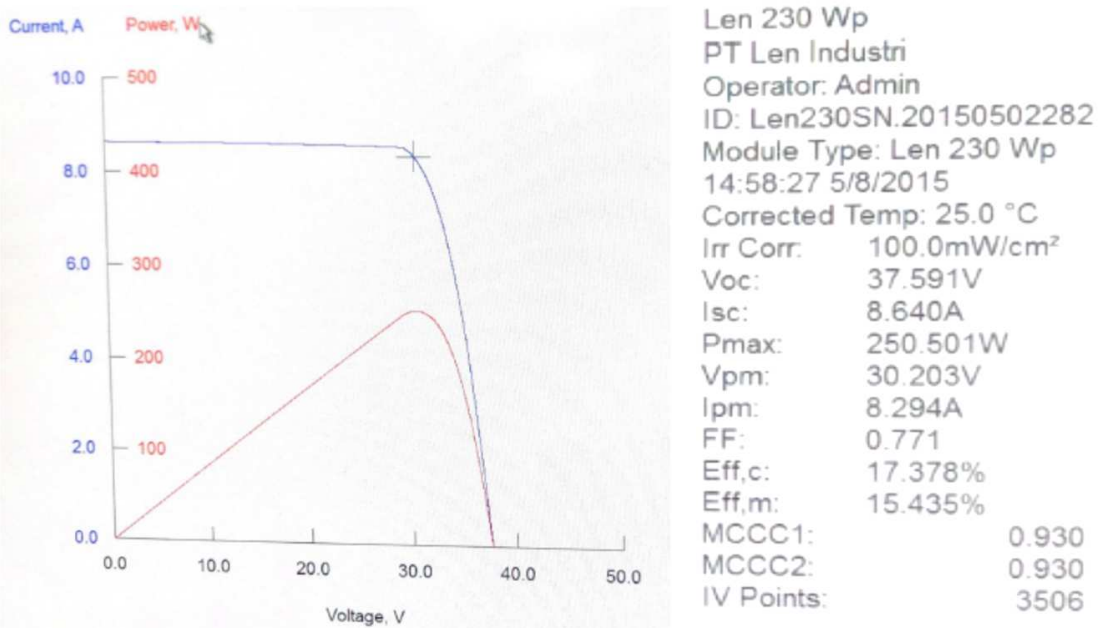

Gambar 8. Hasil Pengukuran Kurva I-V dan karakteristik listrik Modul Surya 240 Wp (sampel-2)

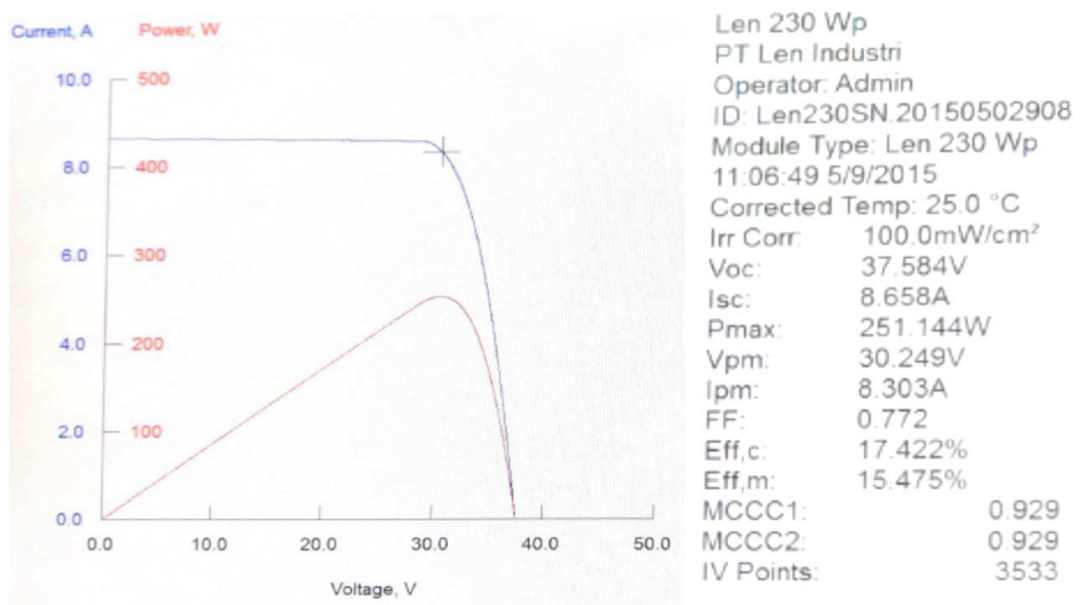

Gambar 9. Hasil Pengukuran Kurva I-V dan karakteristik listrik Modul Surya 240 Wp (sampel-3)

\section{Ucapan Terimakasih}

Penulis mengucapkan terima kasih kepada :

1. Chairul Rizal, ST., staf produksi modul surya PT Len Industri (Persero), yang mendukung data hasil pengukuran Sun simulator tahun 2015 dan 2017.

2. Harry Leo kharisma, ST., Staf Rekayasa proses produksi PT Len Industri (Persero) yang mendukung data pengukuran.

\section{Referensi}

Azwar. (2010). Stabilitas Mekanik Material Multikristal Silicon Wafer pada Pembuatan Sel Surya (Solar Cells). Jurnal POLIMESIN, Volume 12 Nomor 12, Pebruari 2010, ISSN 1693-5463.

Dupont. (2019). Dupont: "Panduan untuk memahami cacat panel surya: dari fabrikasi hingga modul yang 

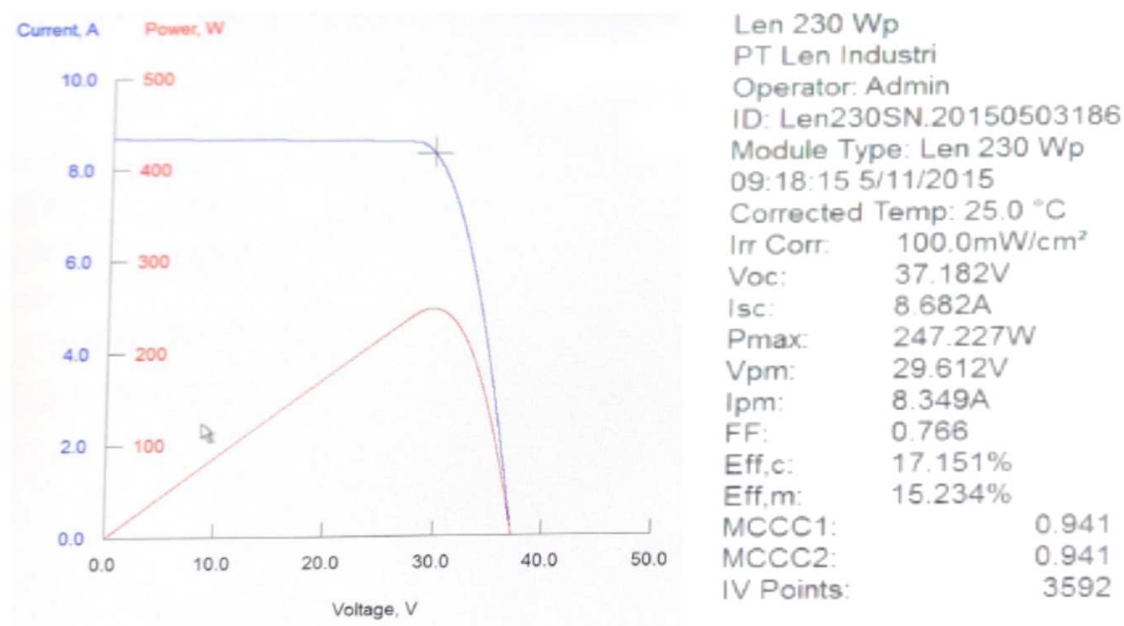

Gambar 10. Hasil Pengukuran Kurva I-V dan karakteristik listrik Modul Surya 240 Wp (sampel-4)

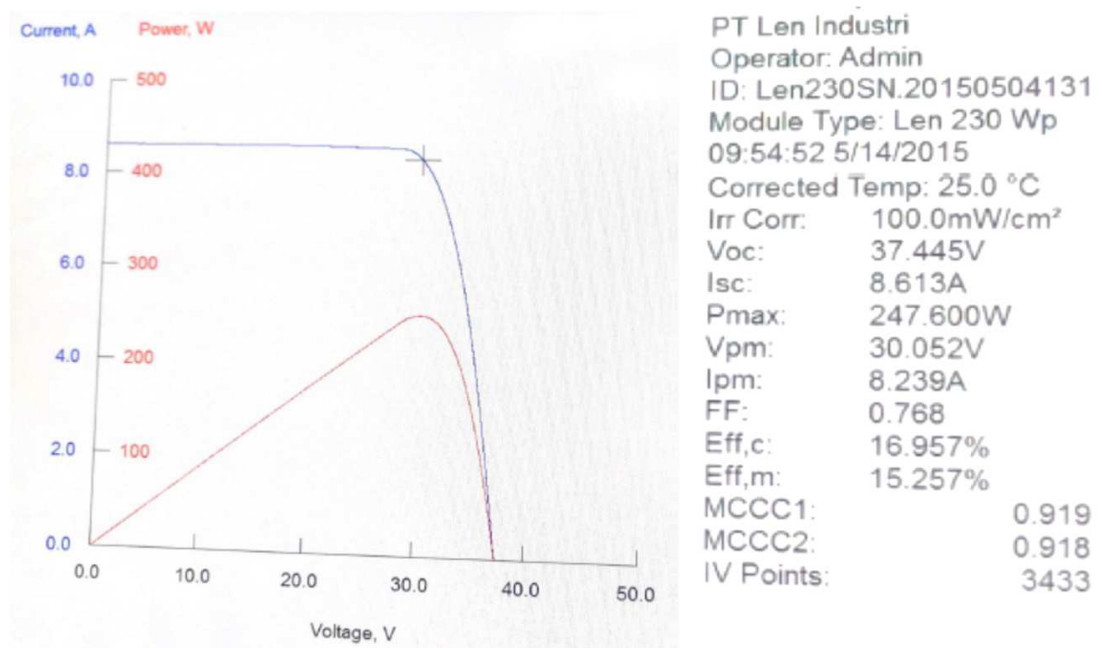

Gambar 11. Hasil Pengukuran Kurva I-V dan karakteristik listrik Modul Surya 240 Wp (sampel-5)

dipasang",. Retrieved April 2021, from Ismet, I., Sopandi, A., \& Sofyan, H. (1999). Fabrikasi Modul www.dupont.com

Faradilla, A. (2017, April 4). Pengujian PV dan
Pendukungnya. Retrieved April 2021, from http://smg.b2tke.bppt.go.id/index.php/2017/04/04/pe ngujian-pv-dan-pendukungnya/

Green, M. (2009). Solar Cells Operating Principles. Technology and System Applications. New South Wales: ARC Centre of Excellence in Advanced Silicon Photovoltaics \& Photonics, Faculty of Engineering, UNSW.

IEC 61215-1-1 :2016 Terrestrial Photovoltaic (PV) module. (2016). Design qualification and type approval part-1-1 : Special requirement for testing of crystalline silicon Photovoltaic (PV) module, MQT 03 Insulation Test.

IEC 61730-1: 2008 Photovoltaic (PV) module safety qualification. (2008). part-1: Requirement for Construction. Annex B (Normattive) Insulation Coordination. Surya \& Peluang Bisnis. Prosiding Pertemuan IImiah IImu Pengetahuan dan Teknologi Bahan'99, 29-31.

Luque, A., \& Hegedus, S. (2011). Handbook of Photovoltais Science and Engineering 2nd Edition. New Jersey: A John Wiley and Sons, Publication.

PLN, S. P. (2015, Januari 9). https://ebtke.esdm.go.id. Retrieved April 2021, from /post/2015/01/09/754/pln.len.teken.ppa.plts.kupang: https://ebtke.esdm.go.id/post/2015/01/09/754/pln.len .teken.ppa.plts.kupang

S.R., W., M.A., G., \& M.E., W. (1998). Applied Photovoltaic. Australia: Centre for Photovoltaic Devices and Systems Australia.

Sitepu, R., \& Gunadhi, A. (2014). Kajian Potensi Pembangkit Listrik Tenaga Surya pada Atap Gedung Kota Surabaya: Studi Kasus Gedung Perkuliahan. The 3rd National Conference on Industrial Electrical and Electronics (NCIEE) Proceedings (pp. 150-154). Jakarta: Universitas Mercubuana. 